\title{
WATER RETENTION IN A SMALL AGRICULTURAL CATCHMENT AND ITS POTENTIAL IMPROVEMENT BY DESIGN OF WATER RESERVOIRS - A CASE STUDY OF THE BÍLÝ POTOK CATCHMENT (CZECHIA)
}

Petr Doležal ${ }^{1}$, Jana Konečná, Petr Karásek, Jana Podhrázská, Michal Pochop ${ }^{2}$

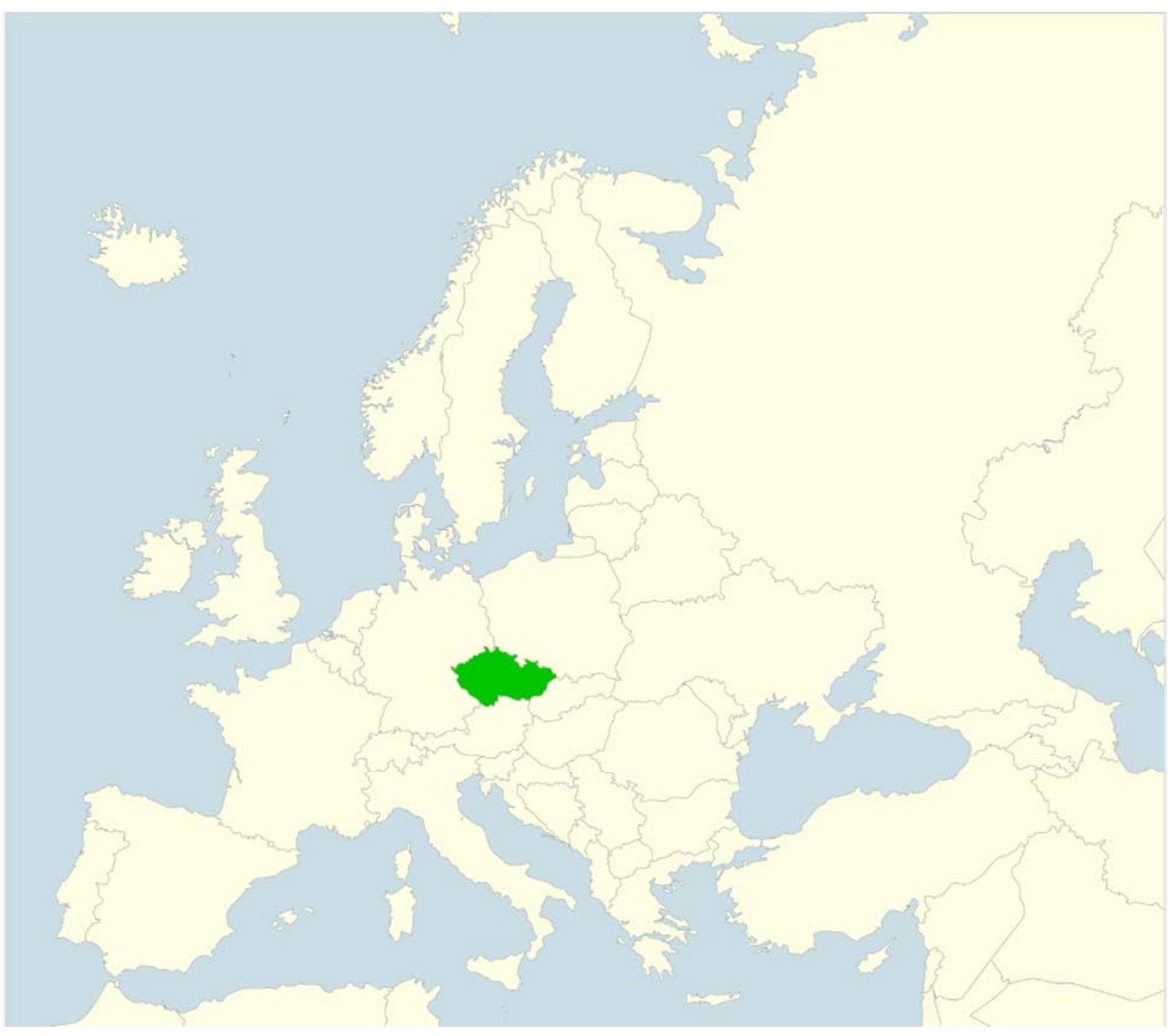

1 Ing. Petr Doležal, Agroprojekt PSO, s.r.o., Slavíčkova 840/1b, 63800 Brno, Czech Republic; e-mail: Petr.Dolezal@AgroprojektPSO.cz

2 Ing. Jana Konečná, Ph.D., konecna.jana@vumop.cz; Mgr. Petr Karásek, karasek.petr@vumop.cz; doc. Ing. Jana Podhrázská, Ph.D., podhrazska.jana@vumop.cz; Ing. Michal Pochop, pochop.michal@vumop.cz; Research Institute for Soil and Water Conservation, Department of Land Use Planning, Lidická 25/27, 60200 Brno, Czech Republic 
Abstract: Water retention in the landscape is discussed in the context of conservation and improvement of both its productive and non-productive functions. We analysed the retention potential of a small agricultural catchment associated with the Bilý potok brook, investigating the possibility to improve its retention capacity and slow down the surface runoff, thus increasing the underground water resources. Method of curve numbers was used for that purposes. From results, it emerged that present maximum water retention in the Bílý potok catchment is $96.2 \mathrm{~mm}$. It could increase by $101.3 \mathrm{~mm}$ in case of grassing about $20 \%$ arable land threatened by soil erosion. As next possibility to retain water from precipitations in landscape, capacity and transformation effect of reservoirs designed in master plans was analysed. The latest programming tools working in the GIS environment were used to assess the retention capacity of both the catchment surface and the reservoirs. Analysing master plans in the catchment, it was found that 16 designed water reservoirs (from 31) have a good potential to intercept water and transform flood discharges. In the result, priority for building of reservoirs was recommended according to their pertinence and efficiency in the studied catchment. Presented complex approach can be widely implemented, especially for better effectivity and cohesion of landscape planning and land consolidations processes.

Key words: Retention reservoirs, land development plan, water retention, drought, floods

\section{Introduction}

Water in the landscape is considered to be one of the key components in the environment as well as a landscape-forming element. By its action, water shapes the landscape physiognomy, creates conditions for life in the landscape, and water bodies are among the most important landscape ecological and aesthetic elements (Bastian, Steinhardt, 2002). Loss of water in the agricultural landscape caused by the current climatic changes may, in the long term, lead to negative changes in the ecosystems biodiversity, productive and non-productive landscape functions, and changes in its overall appearance. That is why now, when recent years brought periods of drought into the Czech Republic, an adequate attention should be paid to the mechanisms of water retention in the landscape and the possibility to effectively retain water in the landscape.

In hydrology, water retention means natural or temporal interception of water in the landscape (Kováŕ, 2006). Water retention is a significant factor in intercepting precipitation and slowing down the surface runoff. It also plays an important role in partial transformation of maximum peak discharge, which helps to limit damage to watercourses and their immediate vicinity. Water retention in the landscape is a strong contributor to elevation of underground water resources by infiltration of precipitation or surface water into lower horizons, with consequent effects on the flow regimes of watercourses in the catchment (Loucks et al., 2005). In these days, when the impact of climatic drought on water abundance in the watercourses is strongly pronounced, the problem has become very pressing. The flow regimes of watercourses are also influenced by water reservoirs, the volume of which can partially improve the lack of water during the dry periods (Williamson et al., 2009).

The issue of water retention in the landscape can be approached using various mathematical models (e.g., Bízek et al., 2011) and methods (e.g., Podhrázská, Spitz, 2000). For solving improvement of hydrological regime in small catchments, some useful models are based on the curve number (CN) method (Janeček et al., 2012). This method can be applied to various catchments and contemplates the surface area representation of land use categories, thus allowing evaluation of the effects of proposed measures aimed at reducing non-point agricultural pollution on the flow and runoff volume in the closing profile of the catchment. Recently, the transformation effect of small water reservoirs has largely been managed using the HEC-HMS model (HEC, 2003; Doležal, Feltl, 2012). 
The basic tools for maintaining and improving the water regime in agricultural landscape in the conditions of the Czech Republic are land consolidations and land development planning. The common facilities proposed during the process of complex land consolidations (such as, e.g., grassing and forestation, interceptive ditches, reservoirs) have shown to be an effective positive means in increasing the potential landscape retention and maintenance of water in the landscape and reducing the unfavourable consequences of floods (Konečná, 2013). Every community has a duty to prepare a master plan defining the basic concept of development of its particular territory, protection of its values, surface and spatial organization, concept of landscape and public infrastructure arrangement, and to ensure the required surfaces for these functions. The level of detail of a master plan does not presume immediate application of the intended measures - this plan, thus represents a conceptual, not implementation document (Pochop et al., 2016). However, the land development plan defines surfaces potentially suitable for design of water reservoirs, which can later be used for their construction during land consolidation.

Pochop et al., (2016) admonish to cooperation and creating close bonds between process of land consolidation and land spatial development. Usually, master plans are disposable and so they are necessarily accepted among working materials for project of land consolidation. In process of a land consolidation, designs of water reservoirs from the master plans had to be considered from the point of view of wider area (local catchment) needs. Method of hydrological analyse of the catchment could help to choose designed reservoirs with the most suitable location and potential to improve water retention in the landscape. Particularly, it also provides reservoir parameters such as volume of retention space.

Analysis of the retention potential of a small catchment was performed within the framework of research project of the Ministry of Agriculture of the Czech Republic QJ1620040 "Optimization of soil and water protection in the water resources catchment with regard to sustainable systems of agricultural management." The project is focused at the Svratka river catchment but the vision is to generalize obtained results and findings to be widely used in the Czech Republic. For the purposes of our analysis, we selected one of the model localities of this project: the Bílý potok catchment (Fig. 1). It is localized in the northern part of the Svratka river catchment. The Bilý potok catchment is a part of the Bohemian Upland province and extends to two different subprovinces. The northeast part belongs to subprovince Bohemian Tableland, more specifically to the Svitavy Plateau. The southwest part of the catchment is situated in the Upper Svratka Highland, which already belongs to the Bohemian-Moravian subprovince. The relief of the Svitavy Plateau is characterized by flat or finely modelled gentle slopes and large valleys of watercourses. The relief of the catchment in the Upper Svratka Highland is steeper and more sharply cut by thalwegs and streams. The peak and extremely sloped parts of the catchment are forested. The mean altitude is $632 \mathrm{~m}$. The mean annual temperature reaches $6^{\circ} \mathrm{C}$ and the mean sum of annual precipitation is about $750 \mathrm{~mm}$ - the prevailing climatic region is wet, moderately cold. The most represented soil types are modal Cambisols on arenic marls and on crystallinicum rocks. Local terrain depressions contain modal Stagnogleys in slope sediments. Watercourses are lined by modal and gleyed Fluvisols and Gleys which have developed on fluvial sediments.

The Bíly potok brook springs eastward from the village Pomezí, which is situated in close proximity of the city Polička. In Polička, it receives the Modřecký and Janský brooks from the south. The longest tributary of the Bilý potok brook is the Černý potok brook, springing in cadastral area Borová, with their confluence located in the village Kamenec u Poličky. From Kamenec, the Bílý potok brook continues to southwest and collects water from additional tributaries from both sides. The important ones are Žlebský potok, Šibeniční potok and Korouhevský potok brooks. The Bílý potok brook empties into the Svratka River in the village of Lačnov. The Bílý potok catchment contains about 36 water reservoirs serving various purposes - mainly ponds and recreations reservoirs, but also reservoirs with sedimentation function (under industrial structures). During field investigations, we confirmed that the existing reservoirs contain very limited storage space, and their effect on transformation of flood waves and retention of precipitation is therefore insignificant. 


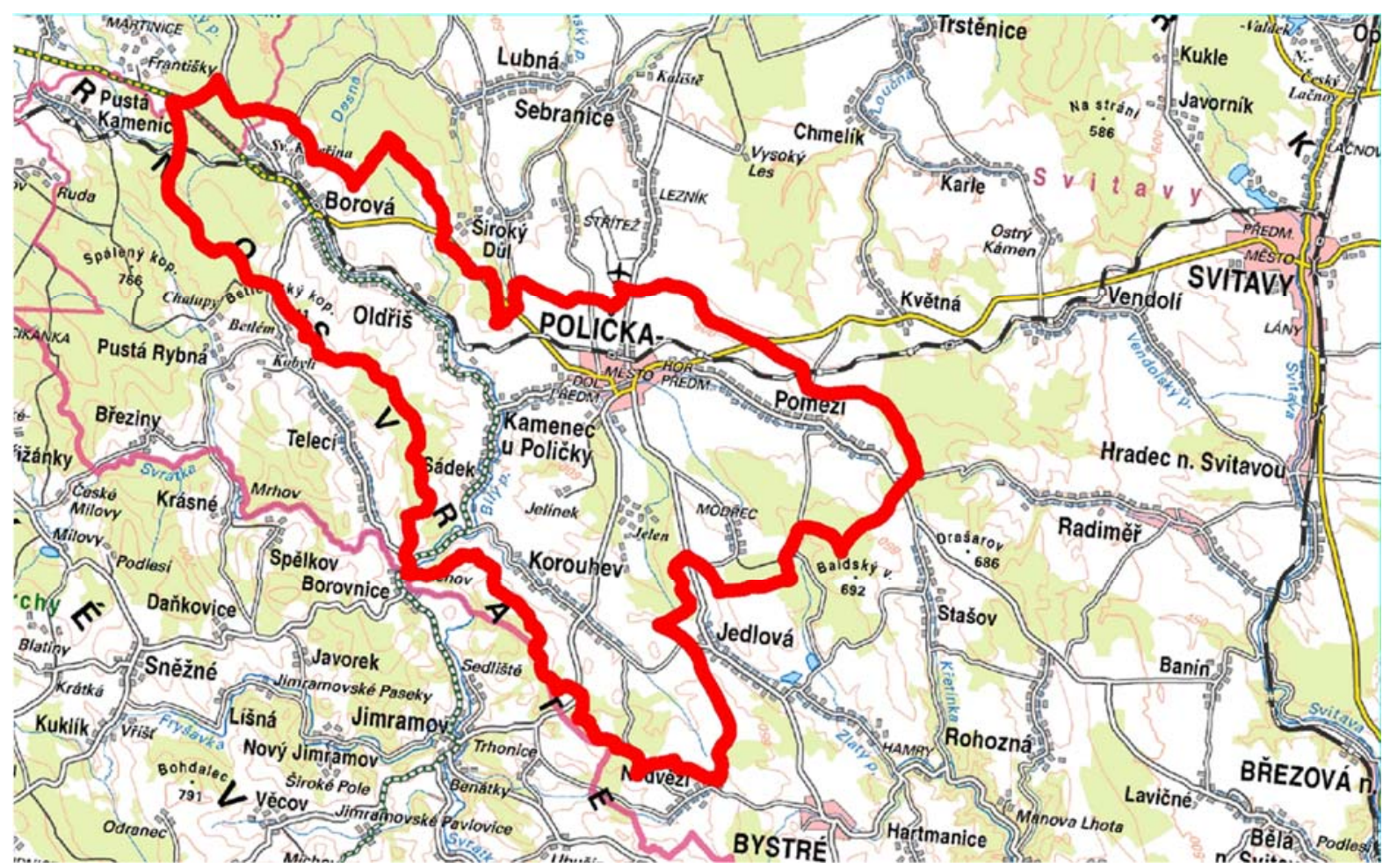

Fig 1. Localization of the Bilý potok catchment.

The study catchment is intensively agriculturally exploited. The arable land covers $36 \%$ of the entire catchment area $\left(A_{c}=100.5 \mathrm{~km}^{2}\right)$, permanent grasslands take $19 \%$, and forests cover $27 \%$ of the catchment surface.

At present, no land consolidations are going on in the communities located in the Bíly potok catchment. Nevertheless all of these municipalities have prepared master plans, as a basic documents including principles and limits of their space development. Natural and anthropic conditions of this chosen model catchment are representative for hilly landscape of the Czech Republic. The area includes highlands with broken relief and also table landscape with long gentle slopes.

\section{Material and Methods}

The purpose of analysing the retention potential was to evaluate the present state of land use and its effects on the retention capacity of the study catchment. To achieve this goal, we used the runoff curve number $(\mathrm{CN})$ method. To assess the potential effectiveness of the retention reservoirs designed in master plans for eliminating harmful consequences of extreme rain-runoff events and utilizing the retained volume to improve the balance of watercourses, we applied the HEC-HMS model (HEC, 2003). The potential retention of the catchment by itself was analysed by the GIS tools, in particular, by program ArcView 9.3, and the retention effect of the studied reservoirs was then processed by program HEC-HMS 4.2.

We used the following basic data:

- Maps of evaluated soil ecological units (ESEU maps) (VÚMOP, 2016).

- Real estate cadastre maps (ČÚZK, 2013).

- Basic maps 1 : 10,000 (ČÚZK, 2010).

- Orthophotomaps (ČÚZK, 2010).

- Digital base of water management data DIBAVOD (VÚV TGM, 2017).

- Digital terrain relief DMR 4G, resolution $1 \times 1 \mathrm{~m}$, elevation standard error $0.3-1 \mathrm{~m}$ (ČÚZK, 2010).

- Land parcel identification system (LPIS) (MZE ČR, 2009). 
- Hydrological data from the Czech Hydrometeorological Institute (CHMI).

- Data on N-annual sums of precipitations in the climatic station Polička (CHMI).

- Results of field surveys.

- Master plans of the cadastral areas in the catchment (text and graphic documents available on municipalities web sides).

The field survey was focused especially on current land use, elements of relief and constructions influencing surface runoff and state and basic characteristics of water bodies. The obtained results were recorded to working maps and descriptions.

\section{Method of runoff curve number}

The curve number (CN) method was developed by the United States Department of Agriculture (USDA) Soil Conservation Service (SCS) for the purposes of estimation of the direct runoff from precipitation in hydrologically non-monitored, mainly agriculturally exploited catchments (Mishra, Singh, 2003). The method is based on the assumption that the ratio between the direct runoff volume and the sum of storm runoff is equal to the ratio between the volume of water retained during the runoff and the potential volume that can be retained (e.g., Janeček et al., 2012). The method assumes that the value of the total direct runoff resulting from the causative precipitation is a function of the value of cumulative precipitation, land use, soil cover properties, and previous saturation of the soil profile. Calculation of the direct runoff (e.g., Soulis, Valiantzas, 2012) is done according to the simple formula:

$$
P_{e}=\frac{\left(P-I_{a}\right)^{2}}{P-I_{a}+S},
$$

wherein:

$P_{e}=$ cumulative value of the direct runoff in $\mathrm{mm}$ for time interval $\mathrm{t}$,

$P=$ cumulative value of precipitation in $\mathrm{mm}$ for time interval $\mathrm{t}$,

$l_{a}=$ initial loss from total precipitation in $\mathrm{mm}$,

$S=$ maximum potential retention

From analysis of results of numerous small experimental catchments, the SCS derived an empirical formula for calculation of the initial loss, which is the sum of interception and surface retention. The initial loss defines the beginning of direct runoff:

$$
I_{a}=0.2 * S \text {. }
$$

This means that the value of direct runoff for the time period $t$ is:

$$
P_{e}=\frac{(P-0.2 * S)^{2}}{P+0.8 * S} \text {. }
$$

The resulting direct runoff is calculated as the difference between the direct runoff at the end and at the beginning of the time interval.

The maximum retention capacity of the catchment is based on the mean $\mathrm{CN}$ value and is calculated using the formula:

$$
S=\frac{25400-254 * C N}{C N} \quad[\mathrm{~mm}] \text {. }
$$

The CN values are given by Janeček et al. (2012), tabulated for the conditions of the Czech Republic according to the soil characteristics and land use. The value close to 100 represents almost impermeable surfaces such as roofs, communications and other hard surfaces. The results of $\mathrm{CN}$ value calculations were used for the analysis of maximum retention of surface in the Bílý potok catchment. 


\section{Transformation of direct runoff - unit hydrograph method}

This method uses a transformation function based on the principle that the hypothetical catchment response to the unit effective precipitation is always the same for the rainfall of defined duration. Hydrological models often utilize the unit hydrograph, because the known sum of effective precipitation directly defines the form of the flood wave, and thus also the magnitude of the culmination flow. The unit hydrograph (Singh, Mishra, Jain, 2014) is defined as a hydrograph of direct runoff induced by effective rainfall of unit volume, constant intensity and uniform distribution in the catchment, while assuming validity of the principle of superposition and principle of time invariance.

In program HEC-HMS, we selected the unit hydrograph according to Singh and Woolhiser (2002), described by the following parameters:

$T_{c}=$ concentration time $[\mathrm{h}]$,

$R=$ transformation factor of the catchment [h], simulating the time of water retention in the catchment.

To calculate the concentration time $T_{c}$, we selected the SCS-CN method (Mishra and Singh, 2003, Soulis and Valiantzas, 2012) in order to derive TLAG (time lag in hours between the occurrence of maximum causative precipitation and the occurrence of culmination flow in the calculated closing profile of the catchment).

$$
T_{\text {LAG }}=\frac{\left(3.281^{*} L\right)^{0.8}(0.04 * S+1)^{0.7}}{1900 \sqrt{Y}} \quad \text { [h] }
$$

wherein

$L=$ length of distance from the thalweg to the divide [m],

$S=$ is the maximum potential catchment retention [mm],

$Y=$ is the mean catchment slope [\%].

The concentration time $T_{C}$ is then estimated according to the formula:

$T_{c}=1.67^{*} T_{\text {LAG }} . \quad[\mathrm{h}]$.

Only a minimum of calculation formulas exist to determine the $R$ coefficient. Typically, for calculations of the theoretical flood wave in non-monitored catchments, the value of coefficient $R$ is estimated as $n$-fold concentration time:

$R=n^{*} T_{c}$.

This formula contains parameters $R$ and $T_{c}$ according to Singh and Woolhiser (2002), as defined above. The value of $n$ mostly lies in the interval $1.2-2$.

\section{Modelling of flow in the river network}

To calculate flows in the studied catchment, we used the Muskingum method in HEC-HMS (Neitsch, Arnold, Kiniry, Williams, 2005). This method is used in cases when almost no data describing the watercourse bed (the bed form, roughness, etc.) are available. It is described by equation (8) based on the balance of runoff from and influx into the given section of the river bed. 
$V=K *[\mathrm{X} * \mathrm{I}+(1-\mathrm{X}) * \mathrm{O}]$,

wherein

$V=$ retained volume in the river section $\left[\mathrm{m}^{3}\right]$,

$K=$ time of flood wave progress through the river section [h],

$I=$ mean influx into the river section $\left[\mathrm{m}^{3} . \mathrm{s}^{-1}\right]$,

$O=$ mean runoff from the river section $\left[\mathrm{m}^{3} \cdot \mathrm{s}^{-1}\right]$,

$X=$ transformation factor, $<0 ; 0.5>[-]$.

Transformation factor $X$ takes values from 0 to 0.5 . The value of 0.5 means maximum retention of the river section and it is selected for river sections with very mild slopes. Sections with very high slopes have the $X$ factor values close to zero, i.e., the river section has no transformation capacity. Usually, the value of $X$ is selected close to 0.2 . Parameter $\mathrm{K}$ represents the time of flood wave progress through the given river section. The rate of the wave progress ranges from 1 to $2 \mathrm{~m} . \mathrm{s}^{-1}$, most often from 1 to $1.5 \mathrm{~m} . \mathrm{s}^{-1}$.

\section{Calibration of rainfall-runoff model}

The calibration of the rainfall-runoff model was performed without considering the reservoirs for two situations. The first represented flow corresponding to the mean repetition time $\mathrm{N}=50$ years, the second to $\mathrm{N}=100$ years. A design hyetograph was used as input parameter, whose shape was derived according to Šercl (2009) for catchments not exceeding $500 \mathrm{~km}^{2}$. The sum of the causative precipitation corresponded to the daily sum with the mean repetition time of $\mathrm{N}=50$ years and $\mathrm{N}=100$ years. To assess the rate of identity between the measured and model hydrographs in individual profiles, we used the Nash-Sutcliffe (NS) criterion E (McCuen, Knight, Cutter, 2006), which is used for evaluation of hydrological models:

$$
E=1-\frac{\sum_{i=1}^{n}\left(Q_{O B i}-Q_{\text {SIMi }}\right)^{2}}{\sum_{i=1}^{n}\left(Q_{O B i}-\overline{Q_{O B}}\right)^{2}},
$$

wherein:

$Q_{\mathrm{OBi}}=$ observed flow for $\mathrm{i}^{\text {th }}$ time $\operatorname{step}\left[\mathrm{m}^{3} . \mathrm{s}^{-1}\right]$,

$Q_{\text {SIMi }}=$ simulated flow for $i^{\text {th }}$ time step $\left[\mathrm{m}^{3} \cdot \mathrm{s}^{-1}\right]$,

$\bar{Q}_{\mathrm{OB}}=$ mean observed flow for the entire time series $\left[\mathrm{m}^{3} \cdot \mathrm{s}^{-1}\right]$.

Calibration of the rainfall-runoff model was done for the theoretical flood shapes determined by $\mathrm{CHMI}$ in six profiles on the Bíly potok brook (Fig. 2). The profiles in the Fig. 2 were determined below inflows of all significant tributaries. For the same profiles, we evaluated the effectiveness of the reservoirs under consideration. This allowed us to assess the effect of the system of reservoirs on the main watercourse represented by the Bílý potok brook. 

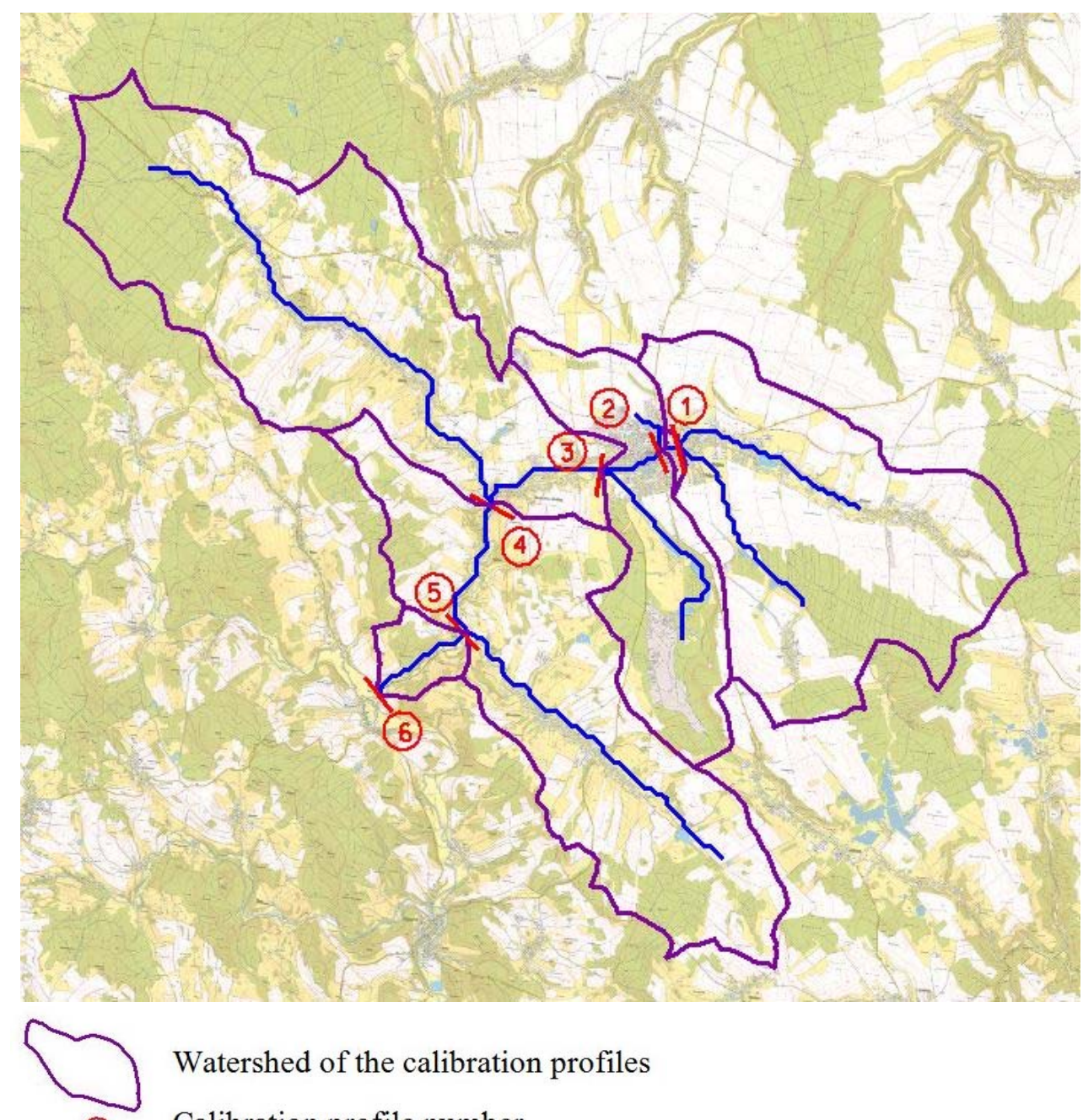

Watershed of the calibration profiles

(2) Calibration profile number

1 Calibration profile

Brooks

Fig 2. Calibration profiles on the Bilý potok course and delineation of partial catchments.

\section{Analysis of maximum retention in the catchment}

The analysis was done by the GIS tools. In program ArcView, we created the layer of land use categories. As basic documentation for this layer, we used the map of real estate cadastre and data related to the land use categories according to the cadastral directive. Further, we used the ESEU map layer (VÚMOP, 2016) providing information on the soil characteristics. Based on the hydrological soil group data and information on the land parcel types and agricultural land use, we generated the layer of the curve numbers. By analysing the watercourse network, we obtained partial catchments. For this purpose, we used the information system DIBAVOD (VÚV TGM, 2017) describing the borders of partial catchments. These partial catchments were then analysed in the GIS, providing statistical parameters on CN representation as area - weighted averages. The results of this analysis showed representation of particular $\mathrm{CN}$ categories in dependence on the vegetation cover and soil types within the partial catchment, and thus the possibility of increasing the catchment surface maximum retention. The values of maximum retention for particular $\mathrm{CN}$ categories were established according to formula (4).

Municipalities master plans identify that $20 \%$ of arable land is threatened by water erosion in the Bílý potok catchment. Nevertheless, there are no specified erosion control measures. They are usually designed and subsequently implemented in process of land consolidation but it does not run in studied catchment. Erosion control measures (belt or areal grassing, foresting, balks, ...) have poly-functional character. Besides soil protection, they also influence water 
retention and ecological values of the landscape. Calculation of maximum retention potential of all the Bílý potok catchment was made in two variants: for existing state and for case of grassing of mentioned $20 \%$ of arable land.

\section{Analysis of the retention capacity of chosen reservoirs}

This analysis was also performed by the GIS tools using programs HEC-Geo HMS and HECHMS. The first program allowed creation of approximation of the current catchment, using a system of partial catchments and sections of the watercourse. Data generated by the system served for simulation of the mean $\mathrm{CN}$ values for the partial catchment: its hydrographic characteristics (mean slope, thalweg length, area, lengths of partial watercourse sections and their slope) and estimation of the concentration time. The generated results and data on the reservoirs were then applied as entries for further calculations in the HEC-HMS environment. This model created a basic data system allowing simulation of the rainfall-runoff process in the catchment (Fig. 2).

Field survey has confirmed that of the existing reservoirs in the catchment, 36 are significant and mostly represent small ponds for fish breeding, or recreation or landscape-forming reservoirs without relevant retention space.

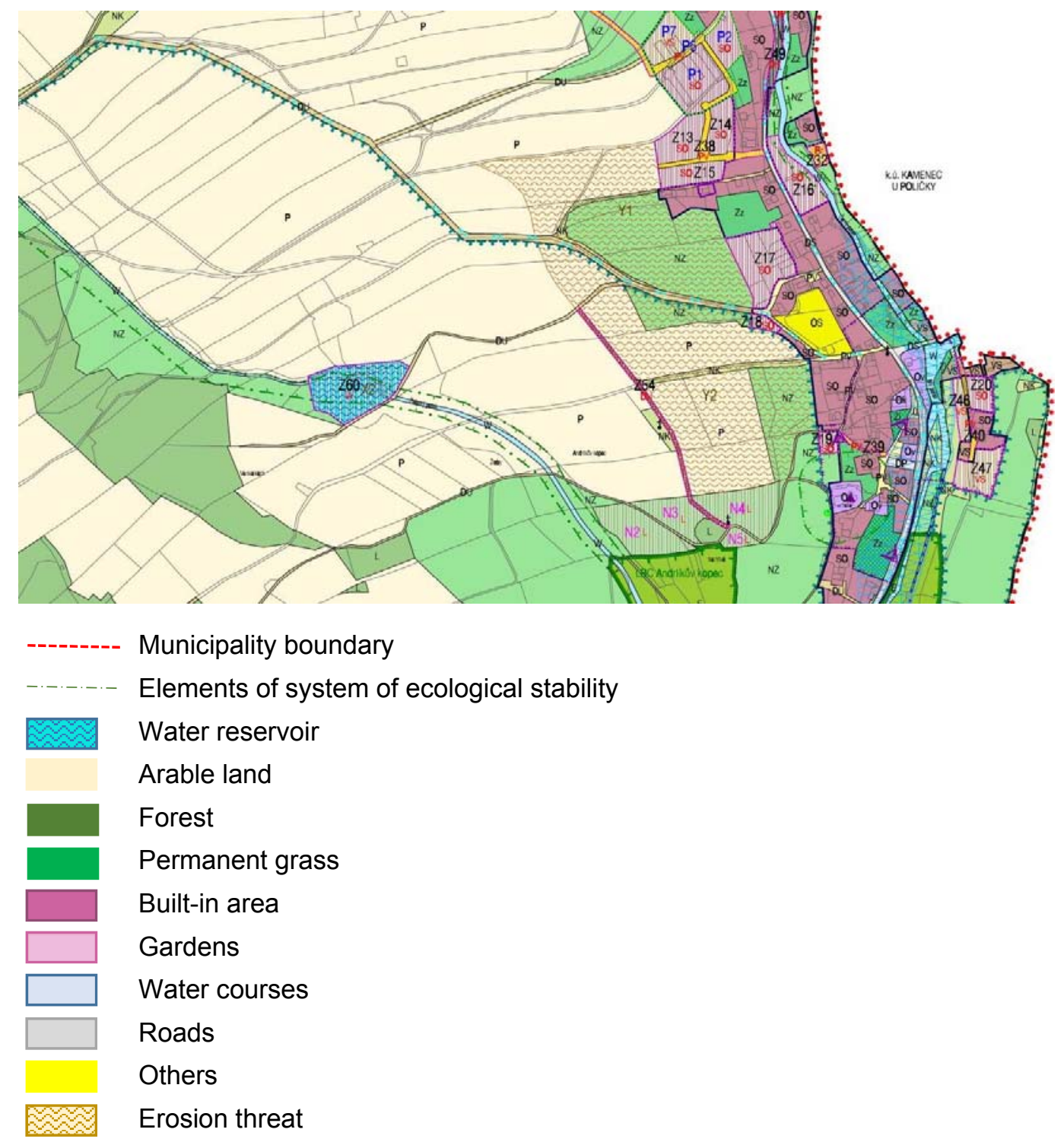

Fig 3. Detail of master plan of Kamenec with designed reservoir N7. 
We further performed analysis of master plans (Fig. 3). In the study catchment, altogether 31 new reservoirs for various purposes have been designed. Of these, based on assessment of the catchment area above the reservoirs, valley shape and designed localization, we selected 16 reservoirs (Fig. 4) with high retention potential, also due to the fact that they represent dry retention reservoirs. Watersheds related to the dams of the studied reservoirs are highlighted in Fig. 4 by green lines. As it was mentioned, existing reservoirs in the model Bílý potok catchment have very small space to incept bigger amount of flood water. That is why we focused on those chosen 16 designed, wanting dry reservoirs and evaluated their potential.

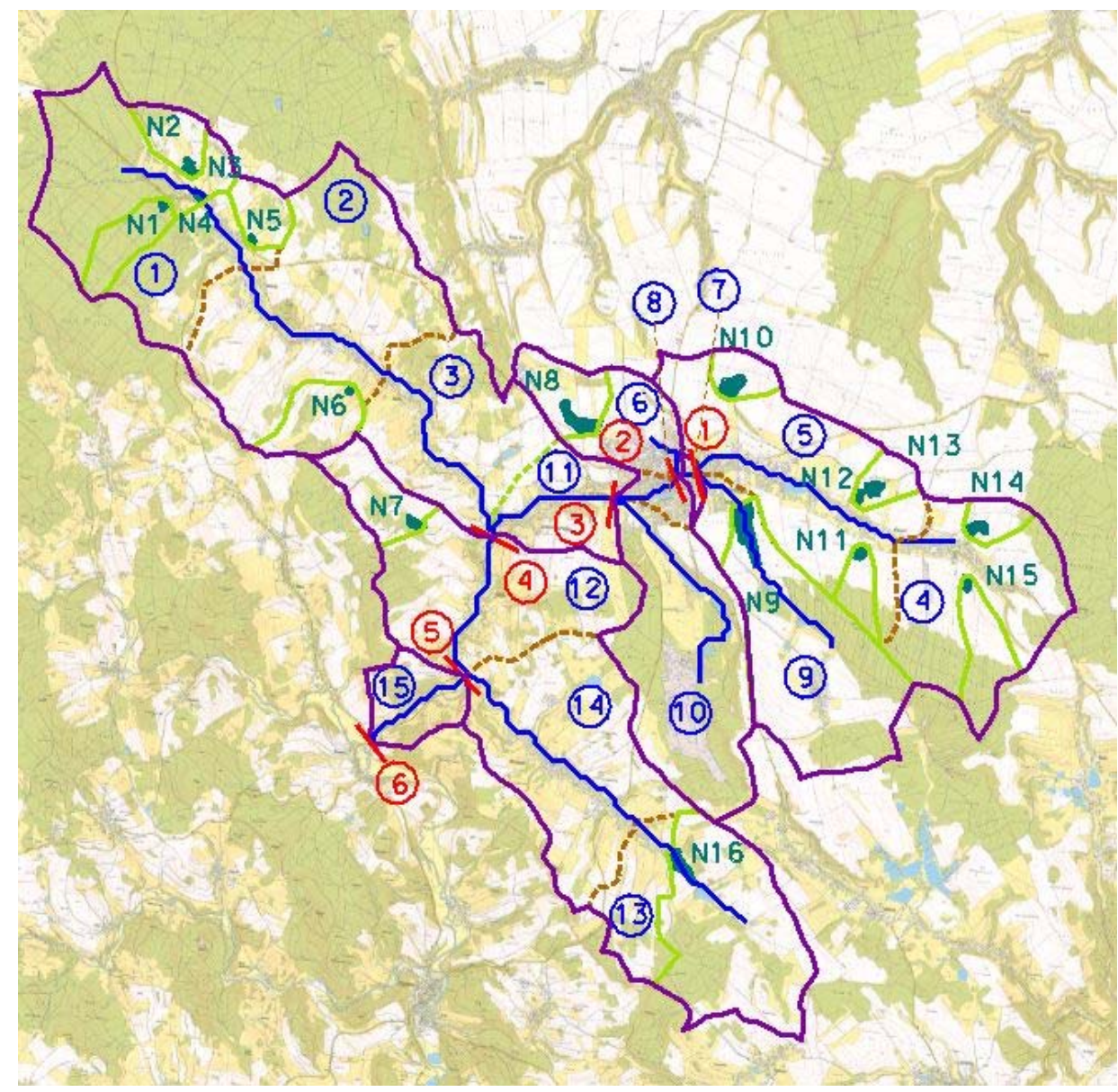

Watershed of the calibration profiles
Calibration profile number
Calibration profile

Fig 4. Localization of the selected reservoirs (N1 - N16) and their catchments.

The selected reservoirs were introduced into the rainfall-runoff model. The situation of the reservoirs was determined according to the master plans, and the characteristics of the reservoirs were estimated from the basic map. We created characteristic lines for the reservoir (reservoir - storage - elevation curves), because master plans do not include any detail technical parameters, but position. The dam height was selected as the maximum possible in the given profile without affecting buildings by reservoir submersion. For all reservoirs, we considered 
the standard mean lower outlet of $0.3 \mathrm{~m}$ and the length of the spillway edge of $6 \mathrm{~m}$ (e.g. Fig. 5). Calibration of the rainfall-runoff model was done for the theoretical flood shapes determined by $\mathrm{CHMI}$ in six profiles on the Bíly potok brook (Fig. 2). The profiles in the Fig. 2 were determined below inflows of all significant tributaries. For the same profiles, we evaluated the effectiveness of the reservoirs under consideration. This allowed us to assess the effect of the system of reservoirs on the main watercourse represented by Bílý potok.

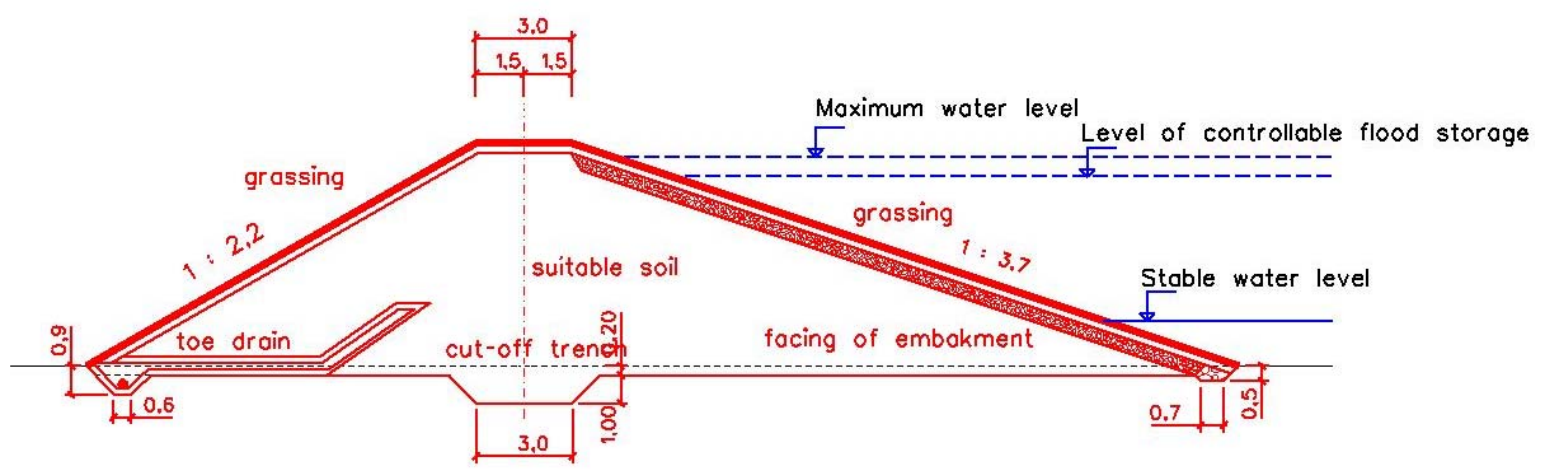

Fig 5. Example of a standard dam.

The system of partial tributaries and reservoirs is reviewed in Fig. 4. It shows the division of the entire catchment into partial subcatchments (blue numbers), allowing better examination of variability of the locality cover and morphology. For example, an elongated catchment is divided into more subsequent parts. This allows taking into account the decay time in the watercourse bed. Dividing was made in the HEC-HMS system. This software recommended area of subcatchments $8-12 \mathrm{~km}^{2}$ because it is optimal from the point of view of reaching demanded accuracy. The resulting approximation of the water bodies net in the HEC-HMS is presented in Fig. 6. This diagram actually shows a topological scheme of approximation of real catchment into system of flows, reservoirs and their structures in the HEC-HMS system. Subbasin elements represents partial catchments, water flows (brooks) are reach elements, reservoirs are reservoir elements, source elements are precipitations. Relations among them represents junction elements (nods) and diversion elements (possibility to disconnect a reservoir for modelling purposes).

After completing the calibration, we performed simulation including the reservoirs. The simulation was done for two variants $\mathrm{V} 1$ and $\mathrm{V} 2$. The first variant $\mathrm{V} 1$ was situation with open bottom outlets. The variant works with the pre-released effect. The variant V2 with closed outlets (only a theoretical case) was enabled to evaluate maximum retention capacity of the reservoirs for the selected parameters (dam dimensions), until the water level reaches the safety spillway. Safety spillways were standardly considered $1 \mathrm{~m}$ below the dam crest and transformation of discharge worked out for reservoirs N4, N6 and N14. The results of the analysis again served for defining conclusions related to the retention capacity of the catchment. 


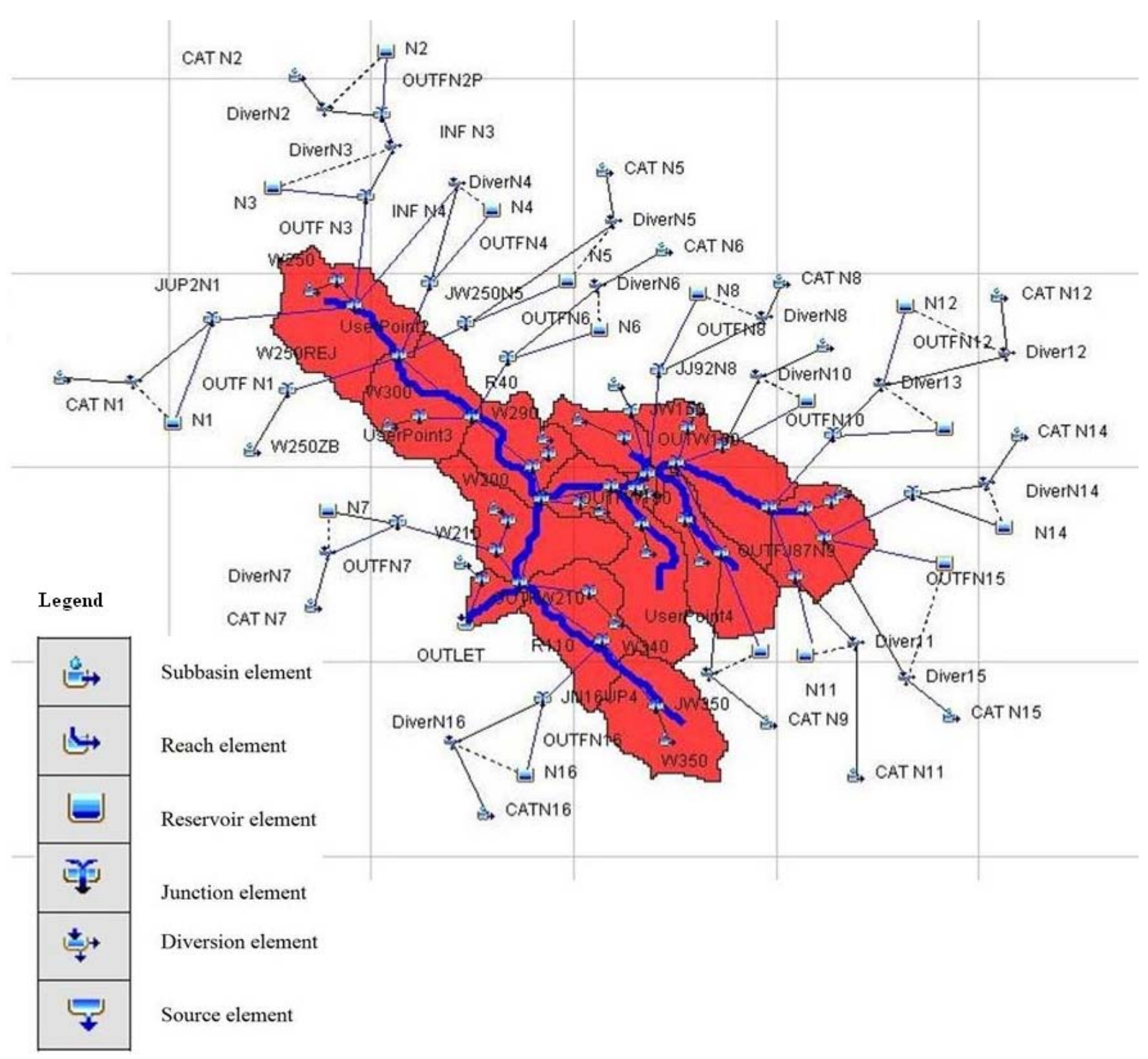

Fig 6. Diagram of the catchment.

\section{Results and Discussion}

\section{Maximum retention of the catchment}

This chapter is focused on the retention potential of surface of Bíly potok catchment. Results of our analysis of the possible increase of water retention in partial catchments were collectively processed in the form of the following tables and graphs. The mean $\mathrm{CN}$ values were calculated as weighted averages, where the weight was represented by the ratio between the $\mathrm{CN}$ number multiplied by its area and the total area of the partial catchment (Table 1).

While analysing and proposing measures to be adopted, we must take into account the ratio between the total area of the partial catchment and the area of arable land in the given partial catchment (Table 2). This ratio will allow delineating those partial catchments, where some organizational measures on arable land might result in increased potential retention. Retention of forest and grass covers in the landscape is higher than that of arable land. It could be reasonably expected that the extent of hard surfaces (particularly built-in areas) would not decrease. The initial values of $\mathrm{CN}$ and potential retention $\mathrm{S}$ for the catchment in the catchment are presented in Figs. 7 and 8. 
Tab 1. Mean values of $\mathrm{CN}$ and maximum retention $S$ for partial catchments.

\begin{tabular}{|c|c|c|c|c|}
\hline Catchment No. & Catchment CN & Arable land CN & $\begin{array}{c}\text { Catchment S } \\
{[\mathbf{m m}]}\end{array}$ & $\begin{array}{c}\text { Arable land S } \\
{[\mathbf{m m}]}\end{array}$ \\
\hline 1 & 65.67 & 77.14 & 139.8 & 75.72 \\
\hline 2 & 71.05 & 76.90 & 110.7 & 76.65 \\
\hline 3 & 72.94 & 78.42 & 102.1 & 70.63 \\
\hline 4 & 72.08 & 78.59 & 106.3 & 69.91 \\
\hline 5 & 77.82 & 79.94 & 78.5 & 64.54 \\
\hline 6 & 81.25 & 78.74 & 65.3 & 69.33 \\
\hline 7 & 91.09 & 82.42 & 28.0 & 54.67 \\
\hline 8 & 89.27 & 76.76 & 37.8 & 77.22 \\
\hline 9 & 72.25 & 77.96 & 106.4 & 72.43 \\
\hline 10 & 69.60 & 77.13 & 120.5 & 75.77 \\
\hline 11 & 77.13 & 77.76 & 81.6 & 73.24 \\
\hline 12 & 71.30 & 77.26 & 109.1 & 75.22 \\
\hline 13 & 71.75 & 77.81 & 106.9 & 73.13 \\
\hline 14 & 74.25 & 77.40 & 93.9 & 74.67 \\
\hline 15 & 62.60 & 76.00 & 156.5 & 80.21 \\
\hline Area average & 74.67 & $\mathbf{7 8 . 0 2}$ & $\mathbf{9 6 . 2 3}$ & $\mathbf{7 2 . 2 2}$ \\
\hline
\end{tabular}

Tab 2. Proportion of selected land use types in partial catchments.

\begin{tabular}{|c|c|c|c|c|c|c|c|}
\hline Catchment No. & $\mathbf{P}$ [ha] & $\begin{array}{c}\text { Arable land } \\
{[\text { [ha] }}\end{array}$ & $\begin{array}{c}\text { Arable land } \\
{[\%]}\end{array}$ & $\begin{array}{c}\text { Forest } \\
{[\text { ha] }}\end{array}$ & $\begin{array}{c}\text { Forest } \\
{[\%]}\end{array}$ & $\begin{array}{c}\text { Hard } \\
\text { surface } \\
\text { s [ha] }\end{array}$ & $\begin{array}{c}\text { Hard } \\
\text { surface } \\
\text { s [\%] }\end{array}$ \\
\hline 1 & 1143.0 & 186.9 & 16.4 & 709.2 & 62.0 & 34.0 & 3.0 \\
\hline 2 & 1253.2 & 550.1 & 43.9 & 276.2 & 22.0 & 60.4 & 4.8 \\
\hline 3 & 655.6 & 285.9 & 43.6 & 102.6 & 15.6 & 36.8 & 5.6 \\
\hline 4 & 775.8 & 395.4 & 51.0 & 253.1 & 32.6 & 42.9 & 5.5 \\
\hline 5 & 1009.3 & 629.1 & 62.3 & 63.9 & 6.3 & 100.8 & 10.0 \\
\hline 6 & 355.1 & 185.9 & 52.3 & 14.4 & 4.0 & 94.5 & 26.6 \\
\hline 7 & 20.6 & 4.2 & 20.1 & 0.01 & 0.1 & 12.9 & 62.8 \\
\hline 8 & 63.6 & 3.2 & 5.1 & 0.4 & 0.6 & 45.7 & 71.9 \\
\hline 9 & 819.1 & 374.7 & 45.7 & 252.3 & 30.8 & 65.4 & 8.0 \\
\hline 10 & 844.8 & 144.2 & 17.1 & 405.6 & 48.0 & 76.9 & 9.1 \\
\hline 11 & 295.9 & 133.8 & 45.2 & 7.1 & 2.4 & 43.6 & 14.8 \\
\hline 12 & 901.5 & 427.6 & 47.4 & 198.3 & 22.0 & 32.0 & 3.5 \\
\hline 13 & 885.4 & 414.8 & 46.8 & 235.7 & 26.6 & 20.4 & 2.3 \\
\hline 14 & 889.9 & 492.4 & 55.3 & 58.5 & 6.6 & 51.7 & 5.8 \\
\hline 15 & 194.0 & 29.0 & 14.9 & 94.2 & 48.6 & 2.1 & 1.1 \\
\hline
\end{tabular}




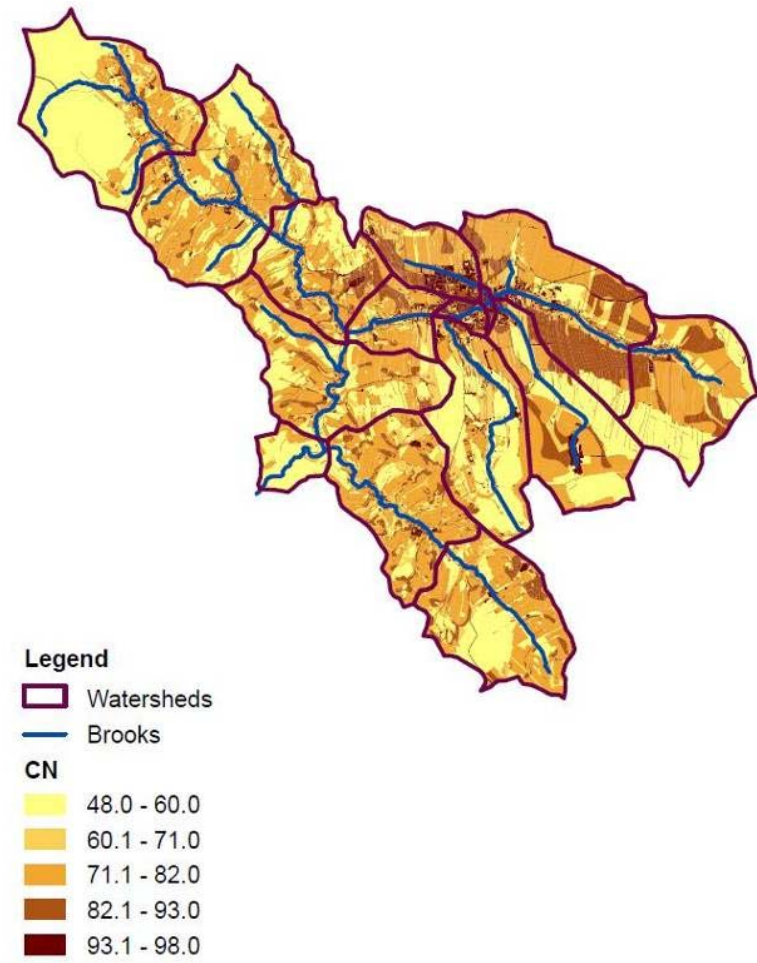

Fig 7. CN representation in the catchment.

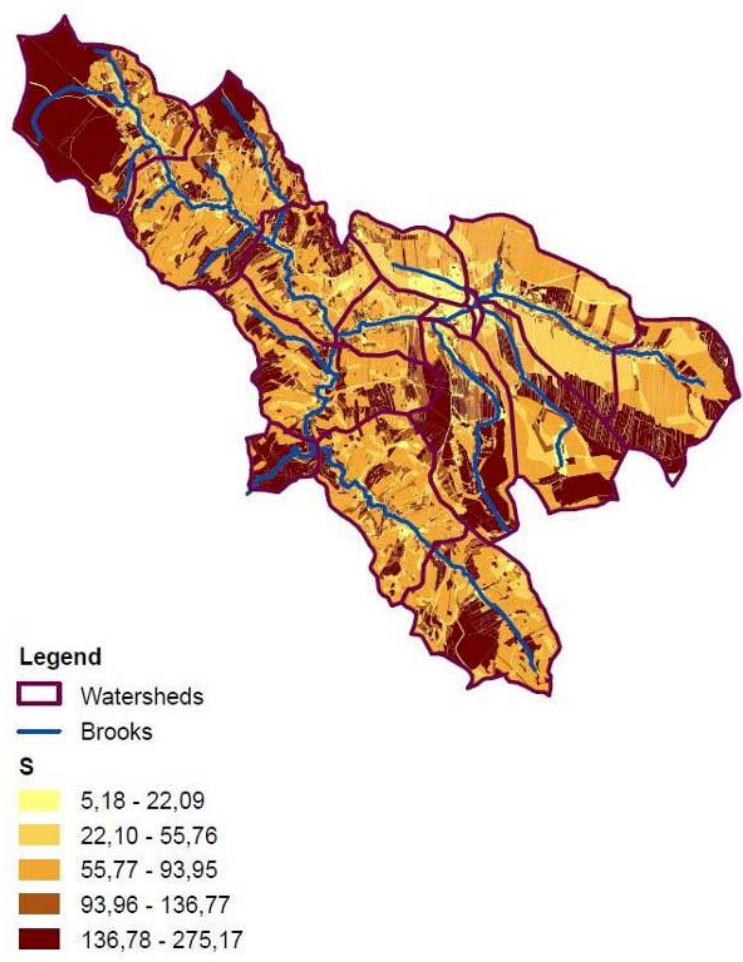

Fig 8. S representation in the catchments.

\section{Retention effect of chosen reservoirs}

The results of calibration of the rainfall-runoff model for $Q_{50}$ (outflow evocated by rain with repetition $N=50$ years) and $Q_{100}(N=100$ years) in 6 profiles (Fig. 2) are summarized in Table 3 and they show a very good correlation, as documented by, e.g., Fig. 9. Values of Nash-Sutcliffe criterion in Table 3 were calculated according to equation (9) for designed discharges $Q_{50}$ and Q100.

Tab 3. Nash-Sutcliffe criterion (E) in profiles selected for calibration of the model for two design flows.

\begin{tabular}{|l|c|c|}
\hline \multirow{2}{*}{ Profile } & \multicolumn{2}{|c|}{$\mathbf{E}$} \\
\cline { 2 - 3 } & $\mathbf{Q}_{\mathbf{5 0}}$ & $\mathbf{Q}_{\mathbf{1 0 0}}$ \\
\hline 1 & 0.993 & 0.996 \\
\hline 2 & 0.986 & 0.988 \\
\hline 3 & 0.992 & 0.994 \\
\hline 4 & 0.909 & 0.977 \\
\hline 5 & 0.977 & 0.986 \\
\hline 6 & 0.971 & 0.982 \\
\hline
\end{tabular}




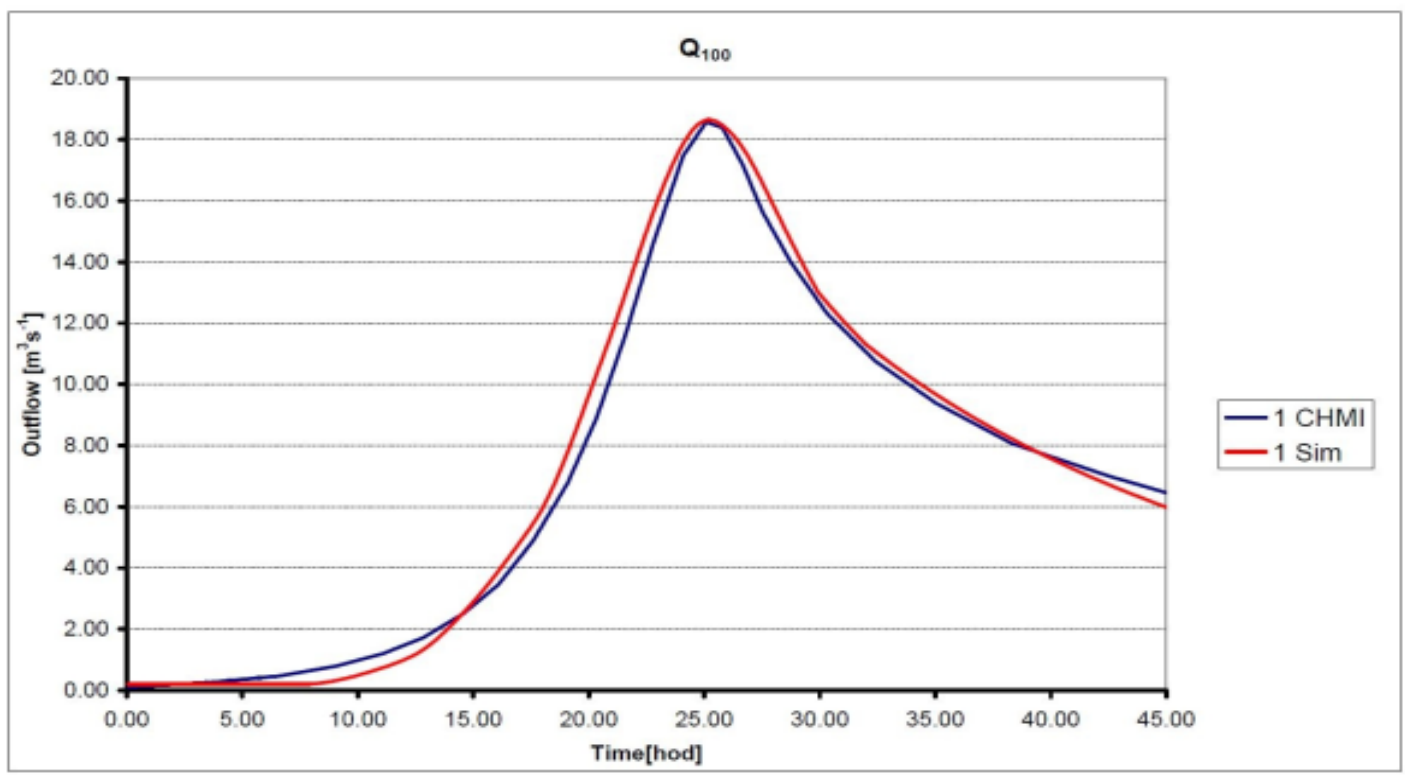

Fig 9. Exemplary correlation between simulated hydrograph (1 Sim) and hydrograph according to CHMI (1 CHMI) in profile No. 1 for $Q_{100 .}$

The results of our analysis focused on the retention effect of reservoirs, according to the master plans in the evaluated profiles 1 to 6 in the Bílý potok watercourse, are presented in Table 4. Variant V1 = open outlets, variant V2 = closed outlets. By this way, reduced flow is compared to unaffected flow.

Tab 4. Retention effect of designed reservoirs in critical profiles.

\begin{tabular}{|l|l|c|c|c|c|}
\hline Profile & Variant & $\begin{array}{c}\mathbf{Q}_{100} \\
{\left[\mathbf{m}^{3} \cdot \mathbf{s}^{-1}\right]}\end{array}$ & $\begin{array}{c}\text { Flow reduction } \\
{[\%]}\end{array}$ & $\begin{array}{c}\mathbf{Q}_{50} \\
{\left[\mathbf{m}^{3} \cdot \mathbf{s}^{-1}\right]}\end{array}$ & $\begin{array}{c}\text { Flow } \\
\text { reduction [\%] }\end{array}$ \\
\hline \multirow{4}{*}{1} & V1 & 15.2 & 18.4 & 12.7 & 17.9 \\
\cline { 2 - 6 } & V2 & 13.9 & 25.4 & 11.4 & 26.3 \\
\cline { 2 - 6 } & Unaffected flow & 18.6 & & 15.5 & \\
\hline \multirow{4}{*}{2} & V1 & 17.4 & 18.9 & 14.6 & 18.3 \\
\cline { 2 - 6 } & V2 & 16.0 & 25.5 & 13.2 & 26.2 \\
\cline { 2 - 6 } & Unaffected flow & 21.4 & & 17.8 & \\
\hline \multirow{3}{*}{3} & V1 & 23.4 & 15.5 & 19.8 & 14.9 \\
\cline { 2 - 6 } & V2 & 22.0 & 20.5 & 18.3 & 21.0 \\
\cline { 2 - 6 } & Unaffected flow & 27.6 & & 23.2 & \\
\hline \multirow{4}{*}{} & V1 & 42.1 & 14.0 & 42.3 & 10.9 \\
\cline { 2 - 6 } & V2 & 40.6 & 17.2 & 40.2 & 15.3 \\
\cline { 2 - 6 } & Unaffected flow & 49.0 & & 47.5 & \\
\hline \multirow{3}{*}{5} & V1 & 57.5 & 14.5 & 51.3 & 12.1 \\
\cline { 2 - 6 } & V2 & 55.2 & 17.9 & 48.4 & 17.1 \\
\cline { 2 - 6 } & Unaffected flow & 67.2 & & 58.4 & \\
\hline \multirow{3}{*}{6} & V1 & 58.1 & 14.4 & 52.1 & 12.0 \\
\cline { 2 - 6 } & V2 & 55.8 & 17.8 & 49.1 & 16.9 \\
\cline { 2 - 6 } & Unaffected flow & 67.9 & & 59.1 & \\
\hline
\end{tabular}

Transformation of designed $Q_{100}$ was calculated for all studied reservoirs. It was found that the modelled discharge passed over the spillway only for reservoirs N4, N6 and N14. Exemplary transformation progress for the reservoir N6 (i.e., reservoir affecting profile No. 4, located in catchment 2 according to Fig. 4) is presented in Figs. 10 and 11. The graph in Fig. 10 corresponds to transformation of flow $\mathrm{Q}_{100}$ and variant $\mathrm{V} 1$, in Fig. 11 to transformation of the same flow and variant V2. In both graphs, the red line in the upper part of the figure shows the course 
of the reservoir filling $\left[1000 \mathrm{~m}^{3}\right]$, the green line shows position of the water level $[\mathrm{m}]$. In the lower part of the figure, the full line shows the influx into the reservoir $\left[\mathrm{m}^{3} \cdot \mathrm{s}^{-1}\right]$, the dotted line shows the outflow from the reservoir $\left[\mathrm{m}^{3} \cdot \mathrm{s}^{-1}\right]$.

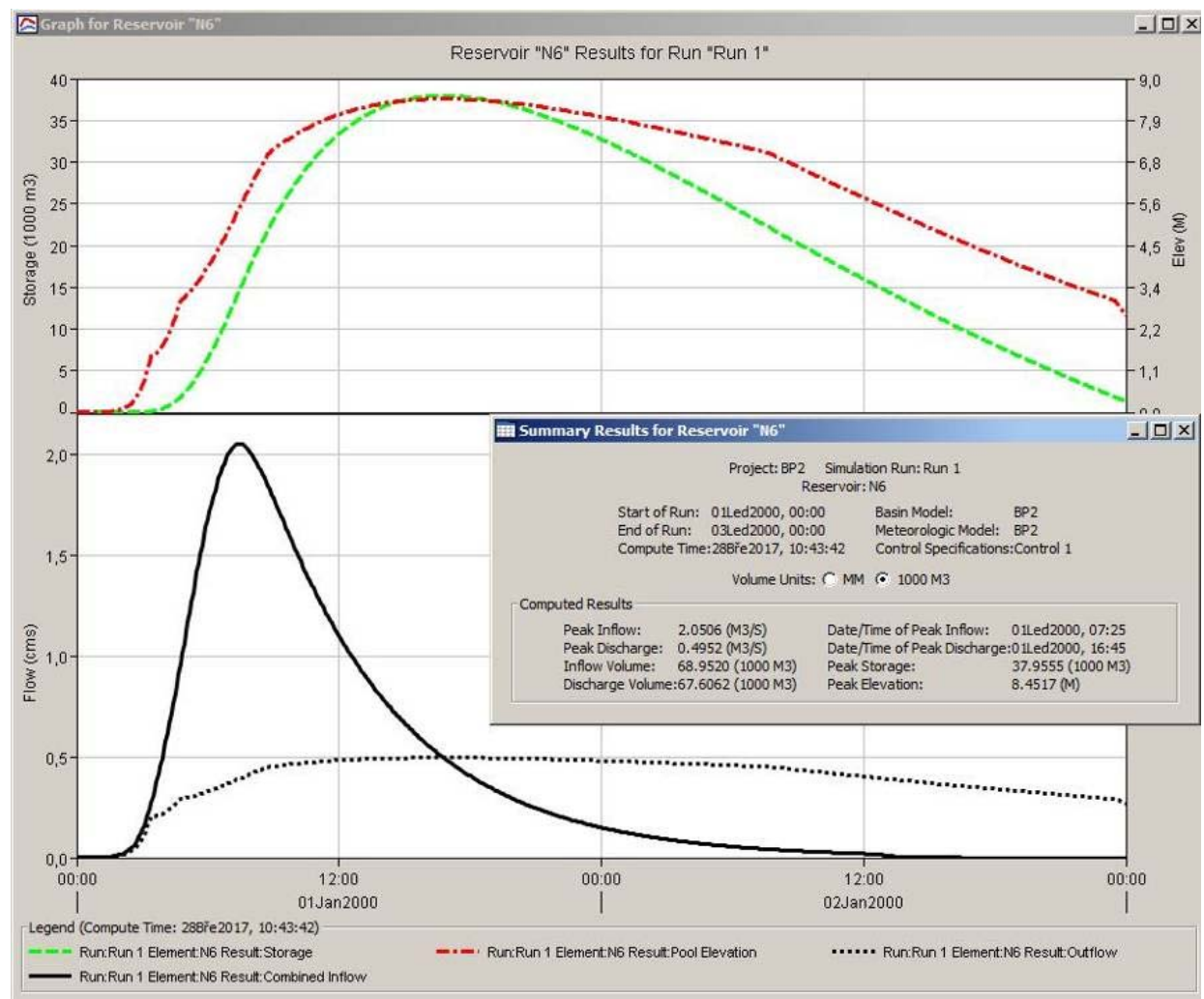

Fig 10. Reservoir N6, variant V1 and flow $Q_{100}$

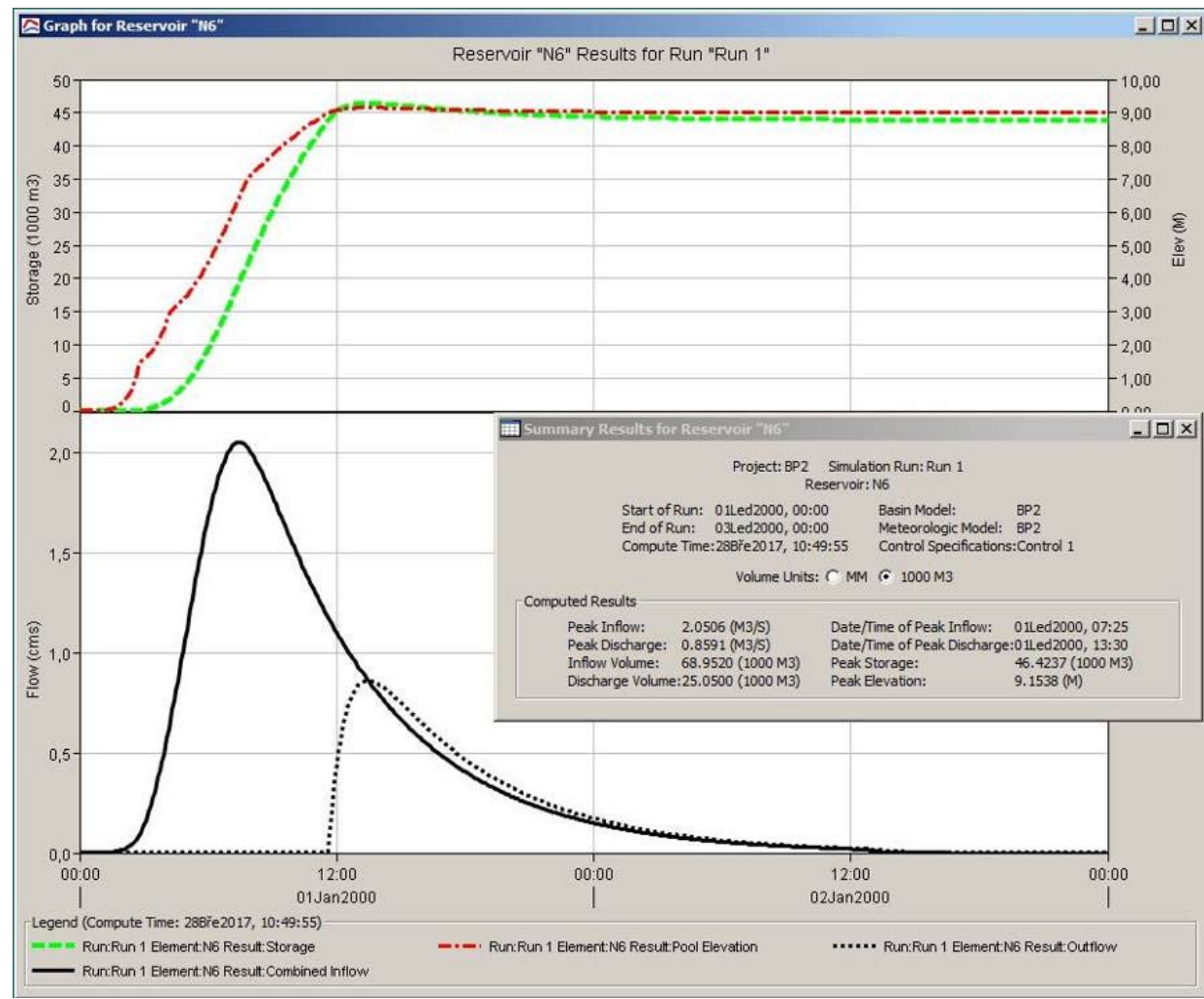

Fig 11. Reservoir N6, variant V2 and flow Q100. 


\section{Summary of results and discussion}

Analysis of the maximum water retention in the catchment (Table 1, Figs. 7 and 8) may lead to the following conclusions. The $\mathrm{CN}$ value for partial catchments is strongly influenced by representation of forests and built-in areas. The highest proportion of forestation is found in subcatchments Nos. 1, 10 and 15. In contrast, the proportion of hard (mainly built-in) surfaces is located in subcatchments Nos. 8, 7, 6 and 11. Potentially, water retention could be significantly increased in catchments with high acreage of agricultural land, because it represents a suitable space for designing organizational (e.g., grassing or forestation), agro-technical (e.g., soilconserving technologies) and technical (e.g., retention ditches, retention reservoirs) measures with multifunctional effects. These measures are currently proposed in land consolidations or land development plans. They slow down the surface runoff, increase water infiltration, retain water in the landscape, reduce soil erosion (Konečná, Podhrázská, Toman, 2012), and thus contribute to increasing the retention potential of the landscape.

Due to the proportion of arable land exceeding $50 \%$ (Table 2), the best prerequisites for efficient design of measures aimed at better water retention in the landscape are in partial catchments Nos. 5, 14, 6 and 4. When considering the results in Table 1, we will see that subcatchments 4, 5 and 6 also show high $\mathrm{CN}$ values and low $\mathrm{S}$ values. So the runoffs caused by precipitation are relatively high and the potential retention low. We can thus conclude that application of suitable erosion control and water management measures in these localities is highly desirable and at the same time actually feasible. The significance of reservoirs for soil and water conservation was described, e.g., by Zhao et al. (2013), highlighting the need for their precise localization in order to achieve the optimum effect. Zubala (2009) observed that a small dam reservoir in an agricultural catchment had positive impact on water quality in the supplying stream the majority of transported contaminants were reduced and the oxygen indicators were improved. In line with Hassall (2014), we can add that water reservoirs contribute a great deal to biodiversity at a regional level as networks of habitat patches that also act as stepping stones to facilitate the movement of species through the landscape.

The surface in subcatchments 7 and 8 is impermeable in more than half of the acreage. These partial catchments contain a high proportion of built-in areas and there is almost no space to implement any measure. Flood protection of the villages is often solved by high-capacity reservoirs above the urban area. However, Dumbrovský and Korsuň (2009), from a larger perspective of water regime in the landscape, recommended the combination of erosion control measures and smaller reservoirs scattered in the source catchment as more favourable. This solution seems to be suitable for protection of built-in areas in mentioned subcatchments.

The mean value of maximum potential retention in all the Bílý potok catchment is $96.23 \mathrm{~mm}$ (Table 1). For partial catchments, the value is in the range from about 28.0 to $156.5 \mathrm{~mm}$. On arable land, the mean value of maximum retention is $72.22 \mathrm{~mm}$ and it ranges from about 64.5 to $80.2 \mathrm{~mm}$ in partial studied catchments. The value of maximum retention can be increased by transforming part of the land parcels into permanent grass covers. By transforming $20 \%$ of arable land to permanent covers (optimally including proposal of erosion control measures) in studied partial catchments, the maximum potential retention capacity could be increased by about $17.2 \%$ (catchment No.1) to $21.9 \%$ (catchment No.5). After the theoretical grassing, the mean maximum retention capacity in the catchment could achieve $101.29 \mathrm{~mm}$ and in partial catchments roughly about 72.4 to $158.43 \mathrm{~mm}$.

Technical parameters of considered reservoirs are described in Materials and methods. Simulation of the rainfall-runoff situations showed that the effect of reservoirs is dependent also on their localization and directly correlates with the surface area of their catchment. The location of the reservoirs is given in Fig. 4. The catchment system of the retention reservoirs takes about $24 \%$ of the total catchment acreage. The highest acreage is taken by reservoir N9 in partial catchment No. 9, with the surface area of 7.5 ha. Another such reservoir is reservoir N16 in catchment No. 13, influencing the area of 6.07 ha. The last major reservoir is reservoir N4, influencing the area of 5.4 ha. Reservoir N4 is strongly limited by localization of buildings, road and railroad. The total influenced acreage is 24.44 ha out of about 101.1 ha of the surface area of the evaluated partial catchment. 
The possible localization of reservoirs is significantly influenced not only by the relief configuration and position of watercourses, but also by the extent of limiting conditions such as built-in areas and position of line constructions (roads and railroads). It is practically impossible to design a reservoir with an extremely high volume on the main watercourses of the Bilý potok catchment. Another limitation are forested areas, abundant in the Bílý potok catchment. An important factor in selecting the reservoir position is the valley shape, as confirmed, e.g., by Louck et al. (2005). Steep valleys have lower retention efficiency because of the lower retention volume achieved with the same dam height than in flat valleys. The considered reservoirs designed in the master plans are therefore situated in flatter localities, with lower relief slopes.

By comparing the possibility to influence position of the reservoirs and their contributing areas we found that the only reservoirs with significant retention capacity are reservoirs N1, N6, N7, N8, N9, N15 and N16. Reservoir N4 is significantly limited by the railroad, built-up area and highway. Because reservoirs N8 and N15 are localized in catchments No. 6 and 4 with a low potential retention, we can state that the need of their build-up is prior to the Bílý potok catchment.

Generally, the location of reservoirs according to the master plans was found to be satisfactory. Their relocation was neither necessary nor possible regarding limiting conditions in catchment. By reason of limited extent of this study, parameters of dams and reservoirs were considered only schematically. Demanded effect of the reservoirs can be reached by optimization of that parameters. Chosen variants V1 and V2 showed only their general potential. Of course, a stable water level would be preferred because such reservoirs increase ecological stability of landscape (Hassall, 2014), contributes to its better aesthetic and have potential to fill other non-productive functions (e.g. recreation). It is supposed that real form, dimensions, volume of retention space and transformation of discharges of every reservoir will be solved individually in the frame of project of a land consolidation.

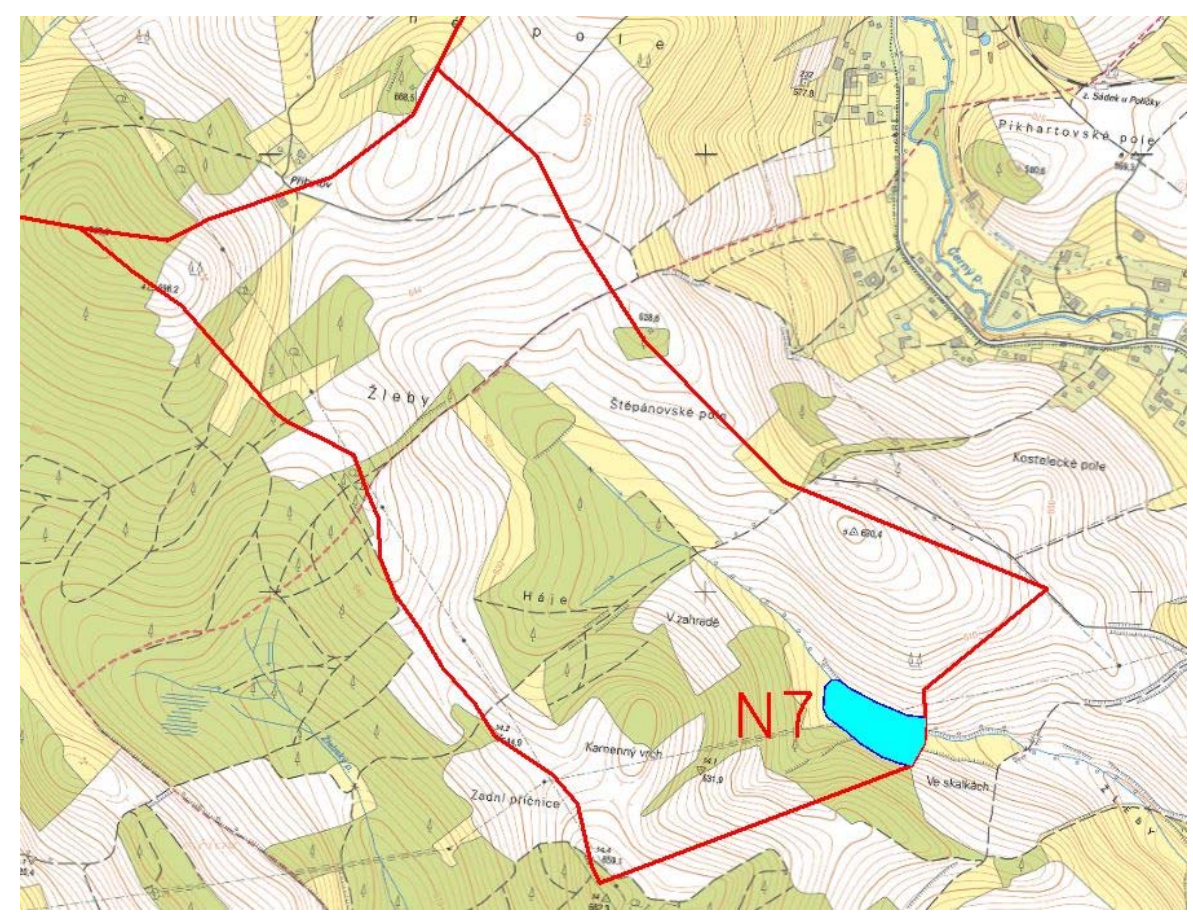

Fig 12. Adjusted shape of reservoir N7 according to hydrological analyse (red line-watershed). 


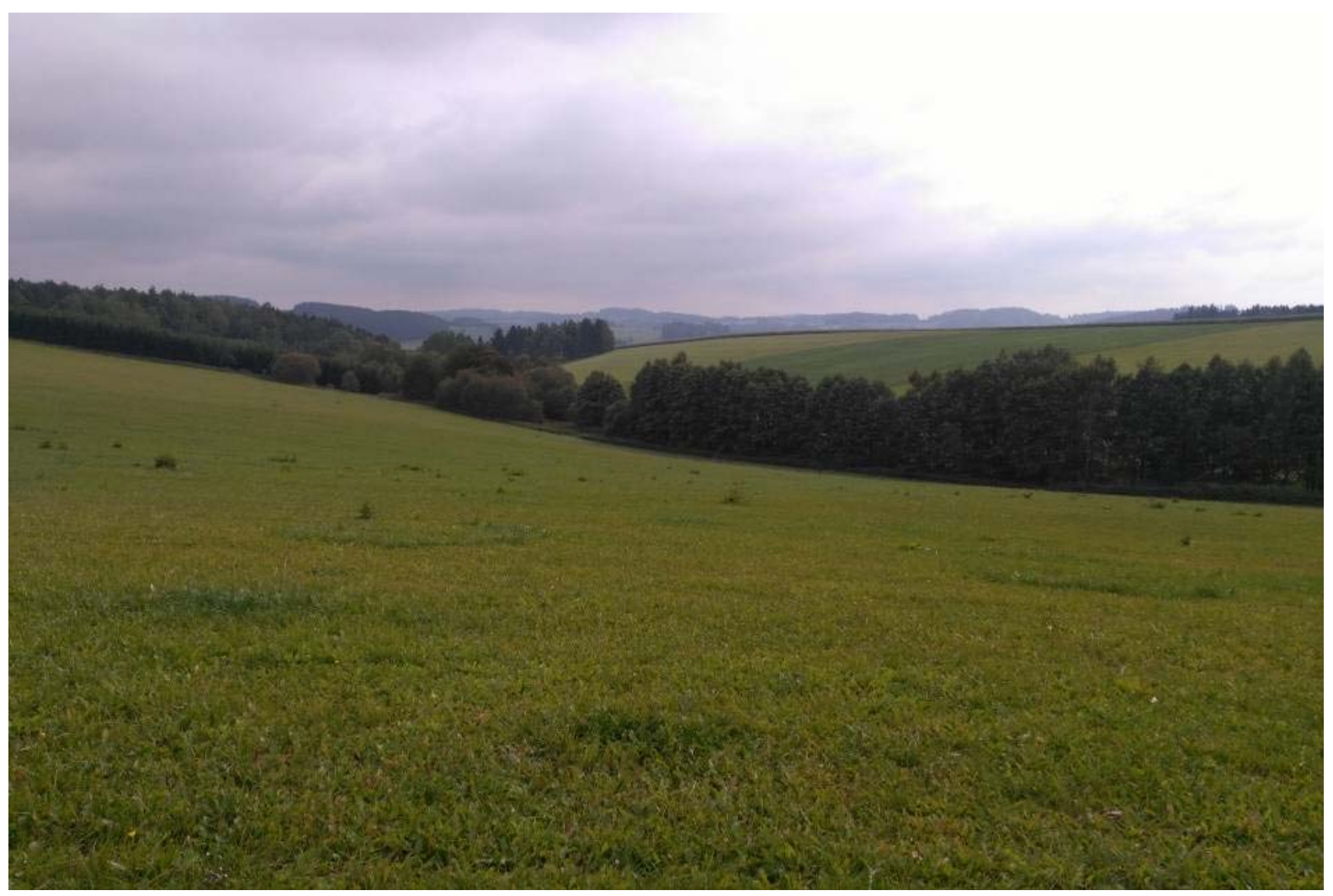

Fig 13. Present state of locality for designed reservoir N7.

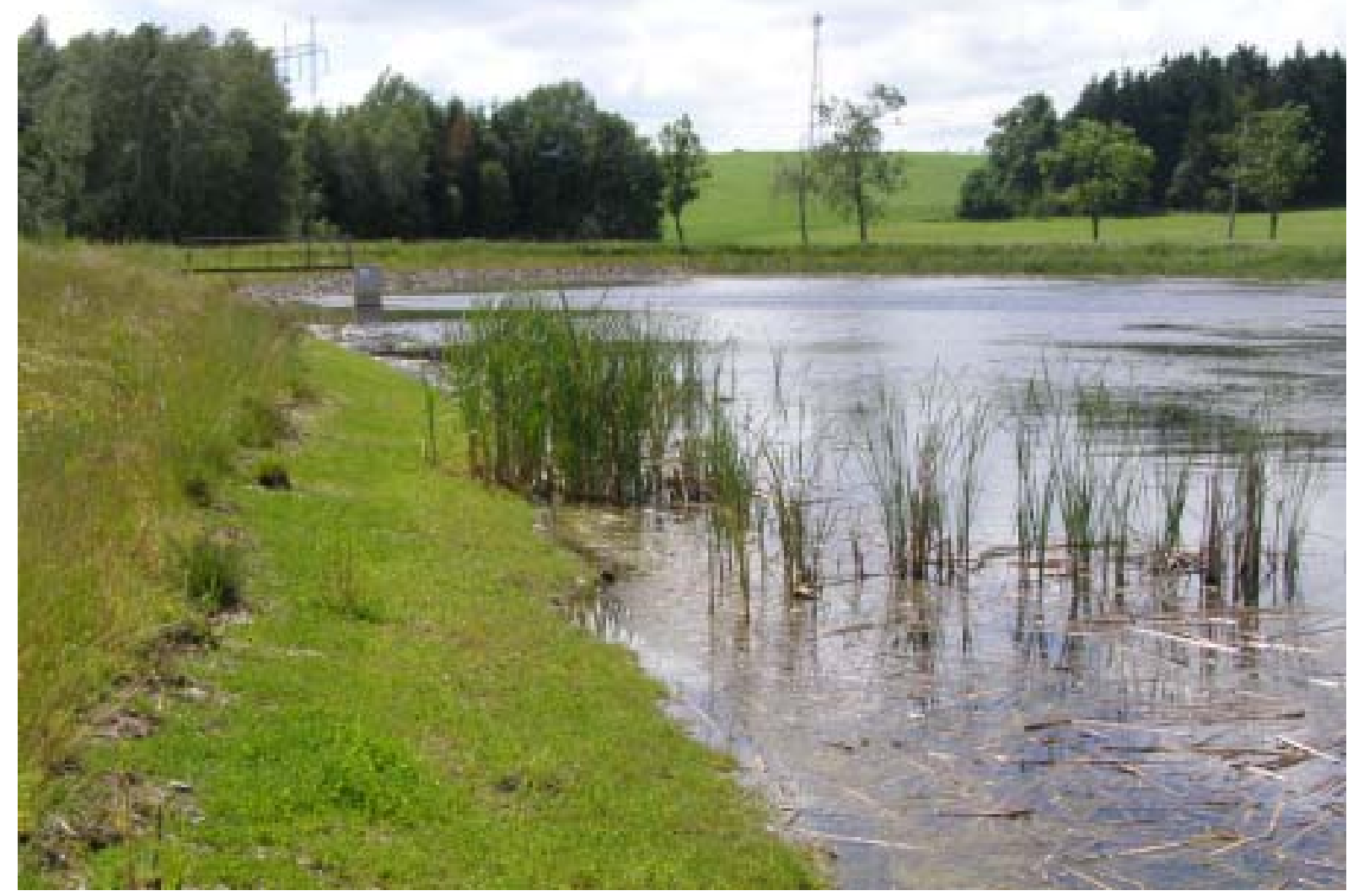

Fig 14. Example of a reservoir with low permanent water level and large retention capacity - near Korouhev in the Bilý potok catchment. 


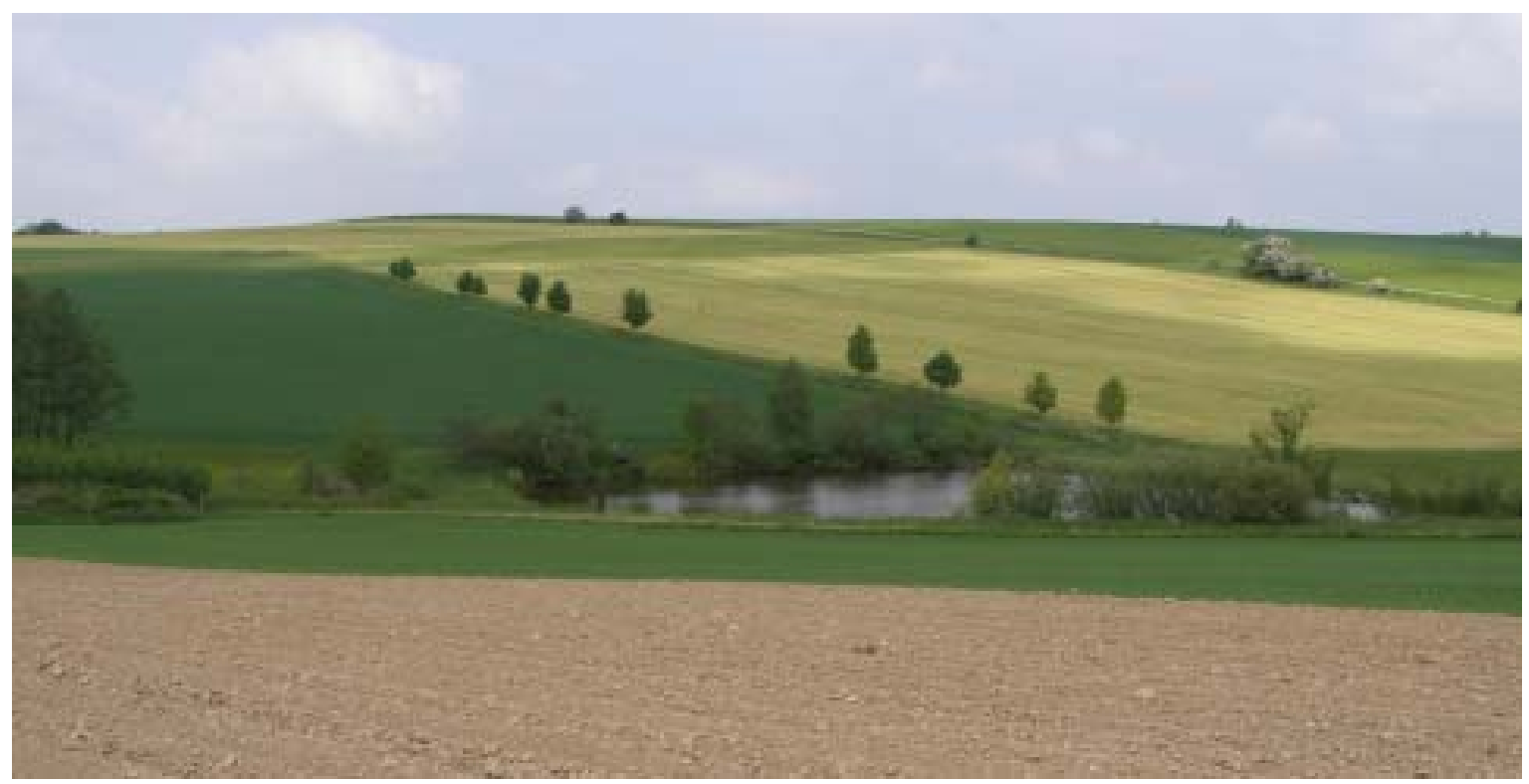

Fig 15. Example of a pond suitably involved in landscape - near Oldřiš in the Bilý potok catchment.

\section{Conclusion}

The extent of maximum retention capacity in small catchments is significantly influenced by representation of surfaces with higher potential retention, depending on the soil characteristics (soil and land parcel type) and land use. Using the CN method, we can generally define the subcatchments that need and actually could increase the maximum retention capacity of a larger territory. While the method is simple and does not consider all effects, it is largely used for hydrological purposes in both professional (design) and scientific practice. The accessibility of digital data makes use of the GIS analyses effective. In conjunction with analysis of erosion risk in agricultural land, the proposal of measures leading to an increase of potential retention of the catchment is relatively easy.

Evaluation of the retention efficiency of technical means such as small water reservoirs is a complex task in small catchments. Analyses have shown that the valley morphology and other limiting conditions such as the extent of development, position of line constructions, and forest abundance play a significant role. Another important factor is the catchment surface area above the reservoirs. Its ratio to the total surface area of the catchment directly defines the extent of the retention effect. Again, the GIS environment has shown itself very favourable for the demanding environmental analyses. Specific hydrological analysis of the Bílý potok catchment has shown the need to perform expert studies that should serve as a basis for delineating reservoirs in master plans of individual communities and, subsequently, for design of land consolidations. To unequivocally confirm the effectiveness of the design, the retention effect of a system of small water reservoirs should always undergo verification.

Land consolidations in the Czech Republic creates a wide space for positive changes in landscape. In frame of this process, erosion control, water management and other ecological measures are designed and implemented. The role of landscape planning is to analyse and determine potential and requirements on development of a municipality in form of master plans. Generally soil and water protective measures are designed only schematically in master plans. In case of retention reservoirs, a suitable location is proposed without technical details. Likewise, supposed submerged area often does not reflect geomorphology above a dam exactly (Fig. 3, 12 and 13).

Presented approach has an ambition to contribute to precise designs of reservoirs in master plans. On the basis of the hydrological analyse, it is possible to reveal whether the reservoir has or has no significant effect of water retain in landscape. The method is based on processing of currently available data using GIS tools and HEC-SMS software and is widely applicable, especially in hilly landscape. It enables to the evaluation of retention potential of surface and 
model effect of changes of land use. The method includes optimization of retention effect reservoirs and its transformation of flood waves. Innovative aspect consists of sophisticated coupling of assessable particular methods into the complex approach to efficiency and feasibility of designed measures with special focus on reservoirs. This is a way how to adopt design of reservoirs from a master plans and to transform them for purposes of a project of land consolidation. In wider area (catchment involving more municipalities or in case of more reservoirs in one territory) the analyses result in determination of recommended priority of reservoirs implementation (mainly in land consolidations). It is advisable to use a part of retention volume in reservoirs for permanent impoundment without significant decrease of retention capacity (Fig. 14). Such reservoirs perform better number of functions in the landscape.

Retention reservoirs in agricultural landscape promote sustainability or even increase of its productive and non-productive functions. Retention of water in the landscape reduces risks associated with the negative consequences of both droughts and extreme rainfall-runoff situations. By that, we mean stabilization of the soil fertility and achieving better ecological stability of the landscape. In particular, if the reservoirs in the landscape are situated with respect to its natural character and complemented with landscape greenery, they contribute to the overall aesthetic appearance of the landscape (Fig. 15). From the viewpoint of the inhabitants of relevant communities and visitors of the localities, these measures increase attractiveness of the environment and promote its recreation and leisure time potential. The impacts on the landscape structure are manifested by changes in both secondary and tertiary structure, with long-lasting overlap into the subjective perception of its emotional potential. Application of novel elements of the technical infrastructure, which water reservoirs undoubtedly represent, is a matter of several years to several decades, but their protective, retention, landscape-forming, or recreation effect is indisputable.

\section{Acknowledgement}

The presented results were obtained thanks to the support of the Ministry of Agriculture of the Czech Republic within the framework of research projects QJ1620040 and MZE RO0216.

Academic References

[1] Bastian, O. \& Steinhardt, U., eds., (2002). Development and perspectives of landscape ecology. Dordrecht: Kluwer Academic Publishers. DOI: 10.1007/978-94-017-1237-8.

[2] Bízek, V. et al. 2011. Aplikace modelů v oblasti životního prostředí. Prague: Cenia.

[3] Doležal, P. \& Feltl, J. (2012). Využití prostorově založeného srážkoodtokového modelu k návrhům malých vodních nádrží s retenčním účinkem. Littera Scripta, 5(1): 201-213.

[4] Dumbrovský, M., Korsuň, S. (2009). Optimisation of soil conservation systems within integrated territorial protection. Soil and Water Research, 4(2), 57-65.

[5] Hassall, C. (2014). The ecology and biodiversity of urban ponds. Wiley Interdisciplinary Review: Water, 1(2), 187-206. DOI 10.1002wat2.1014.

[6] Janeček, M. et al. (2012). Ochrana zemědělské půdy před erozí. [Certifikovaná metodika]. Praha: ČZU: Powerprint.

[7] Konečná, J. (2013). Hodnocení realizací protierozních a vodohospodářských zařízení $v$ pozemových úpravách. [Disertační práce]. Brno: Mendelova univerzita v Brně.

[8] Konečná, J., Podhrázská, J. \& Toman, F. (2012). Efficiency of soil and flood control measures in land consolidations. Acta Universitatis Agriculturae et Silviculturae Mendelianae Brunesis, 60(6), 161-166. DOI: 10.11118/actaun201260060161.

[9] Kovář, P. (2006). The extent of land use impact on water regime. Plant, Soil and Environment, 52(6), 239-244. 
[10] Loucks, D. P. \& van Beek, E. (2005). Water resources system planning and management. Paris: UNESCO. DOI: 10.1007/978-3-319-44234-1.

[11] McCuen, R. H., Knight, Z. \& Cutter, G. (2006). Evaluation of the Nash-Sutcliffe efficiency index. Journal of Hydrologic Engineering, 11(6), 597-602. DOI: 10.1061/(ASCE)10840699(2006)11:6(597).

[12] Mishra, S. K. \& Singh, V. (2003). Soil Conservation Service curve number methodology. Dordrecht: Springer Netherlands. DOI: 10.1007/978-94-017-0147-1.

[13] Neitsch, S. L., Arnold, J. G., Kiniry, J. R. \& Williams, J. R. (2005). Soil and water assessment tool. [Theoretical documentation. Version 2005]. Temple: Texas Agricultural Experimental Station.

[14] Pochop, M., Konečná, J., Podhrázská, J. \& Kyselka, I. (2016). Support of development of landscape not-production functions in spatial planning and land consolidations. In Fialová, J. \& Pernicová, D., eds., Public recreation and landscape protection - with nature hand in hand (pp. 249-256). Brno: Mendel University in Brno.

[15] Podhrázská, J. \& Spitz, P. (2000). Hodnocení retenční schopnosti krajiny při povodni. Acta Universitatis Agriculturae et Silviculturae Mendelianae Brunesis, 49(3), 39-45.

[16] Singh, P. K., Mishra, S. K. \& Jain, M. K. (2014). A review of the synthetic unit hydrograph: from the empirical UH to advanced geomorphological methods. Hydrological Sciences Journal 59(2), 239-261. DOI: 10.1080/02626667.2013.870664.

[17] Singh, V. P., Woolhiser, D. A. (2002). Mathematical modelling of watershed hydrology. Journal of Hydrologic Engineering, 7(4), 270-292. DOI: 10.1061/(ASCE)10840699(2002)7:4(270).

[18] Soulis, K. X., Valiantzas, J. D. (2012). SCS-CN parameter determination using rainfall-runoff data in heterogeneous watersheds. Hydrology and Earth Systems 16, 1001-1015. DOI: 10.5194/hess-16-1001-2012.

[19] Šercl, P. (2009). Vliv fyzicko-geografických faktorů na charakteristiky teoretických návrhových povodňových vin. In Sborník praci Českého hydrometeorologického ústavu, 54.

[20] Williamson, C. E., Saros, J. E., Vincent, W. F. \& Smop, J. P. (2009). Lakes and reservoirs as sentinels, integrators and regulators of climate change. Limnology and Oceanography 54(6), 2273-222. DOI: 10.4319/lo.2009.54.6_part_2.2273.

[21] Zhao, G. et al. (2013). Soil erosion, conservation and ecoenvironment changes in the loess plateau of China. Land Degradation and Development, 24(5), 499-510. DOI: $10.1002 / \mathrm{ldr} .2246$.

[22] Zubala, T. (2009). Influence of dam reservoir on the water quality in a small upland river. Ecohydrology and Hydrobiology, 9(2-4), 165-173. DOI: 10.2478/v10104-010-0010-3.

\section{Other sources}

[23] ČÚZK. @2010. [On line] Available at: http://geoportal.cuzk.cz. [Accessed: 2017, June 15].

[24] ČÚZK. C2013. [On line] Available at: http://services.cuzk.cz. [Accessed: 2017, June 15].

[25] HEC. C2003. [On line] Available at: http://www.hec.usace.army.mil/software/hec-hms/. [Accessed: 2017, March 2].

[26] MZE ČR. @2009. [On line] Available at: http://eagri.cz/public/web/mze/farmar/LPIS/. [Accessed: 2017, June 8].

[27] VÚMOP, v.v.i. @2016. [On line] Available at: http://geoportal.vumop.cz. [Accessed: 2017, May 20].

[28] VÚV TGM. @2017. [On line] Available at: http://www.dibavod.cz. [Accessed: 2017, May 3]. 